\title{
Genetic diversity of the Critically Endangered \\ Philippine EAgle PIthecophaga jefferyi (Aves: ACCIPItridae) AND NOTES ON ITS CONSERVATION
}

\author{
Adrian U. Luczon ${ }^{1}$, Ian Kendrich C. Fontanilla ${ }^{2}$, Perry S. Ong ${ }^{3}$, Zubaida U. Basiao ${ }^{4}$, \\ Anna Mae T. Sumaya ${ }^{5}$ \& Jonas P. Quilang ${ }^{6}$
}

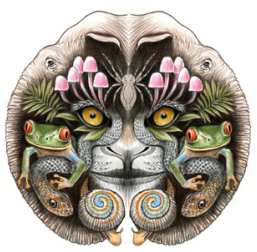

ISSN

Online 0974-7907 Print 0974-7893

OPEN ACCESS

\footnotetext{
$1,2,3,4,6$ Institute of Biology, University of the Philippines, Diliman, Quezon City 1101, Philippines

${ }^{5}$ Philippine Eagle Foundation, Malagos, Baguio District, Davao City 8000, Philippines

${ }^{1}$ adrian.luczon@gmail.com (corresponding author), ${ }^{2}$ ianfontanilla@hotmail.com, ${ }^{3}$ ongperry@yahoo.com,

${ }^{4}$ zbasiao08@gmail.com, ${ }^{5}$ annamae_twisted@yahoo.com, ${ }^{6}$ jpquilang@gmail.com
}

\begin{abstract}
The Philippine Eagle Pithecophaga jefferyi is a diurnal raptor endemic to the Philippines. Its distribution is restricted to remaining forests on the islands of Luzon, Samar, Leyte and Mindanao. The Philippine Eagle is classified as a Critically Endangered species under the IUCN Red List, with a high end estimated population of only 500 breeding pairs in the wild. Population decline has been attributed to continuing deforestation, particularly since the mid-1900s, and hunting. This study aimed to identify the effects of population decline on the genetic structure of the present population of the Philippine Eagle by sequencing $1132 \mathrm{bp}$ of the mitochondrial control region from 22 individuals. Control region haplotype diversity $(h=0.8960 \pm 0.05590)$ and nucleotide diversity $(\pi=0.006194 \pm 0.003372)$ are comparable with other accipitrid species. Maximum likelihood trees and network analysis show that the Luzon and Samar individuals come from different lineages, but both shared a common ancestral population with the Mindanao population. The genetic diversity, multimodal mismatch distribution for the control region and high frequency of lower class modes all indicate a recent bottleneck for the Philippine Eagle population. Possible strategies for conservation are discussed.
\end{abstract}

Keywords: Captive breeding, Critically Endangered, genetic structure, mitochondrial control region, Pithecophaga jefferyi, raptor species.

Abbreviations: CR - control region; DENR-BMB - Department of Environment and Natural Resources-Biodiversity Management Bureau; $\mathrm{H} 1-\mathrm{H} 12$ - haplotypes 1 to 12 of the control region; ML tree - maximum likelihood tree; PCR - polymerase chain reaction; PEF - Philippine Eagle Foundation; SNPs - single nucleotide polymorphisms; UV-Etbr - Ultraviolet - Ethidium Bromide illumination.
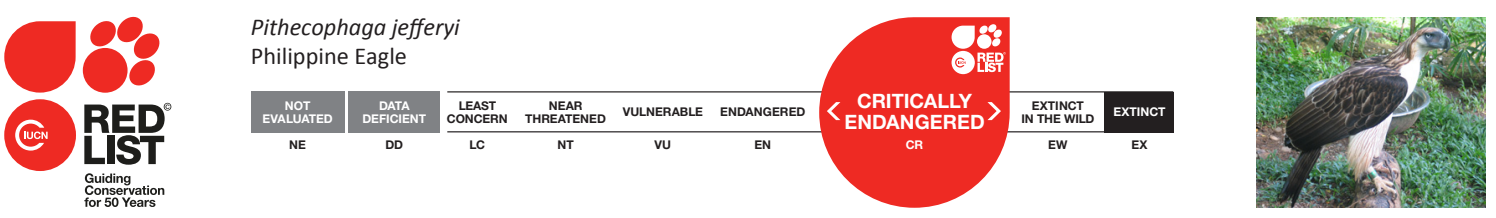

DOI: http://dx.doi.org/10.11609/JoTT.o3748.6335-44 | ZooBank: urn:Isid:zoobank.org:pub:FBCD6920-A726-412F-B106-72B2B834F990

Editor: C. Srinivasulu, Osmania University, Hyderabad, India.

Date of publication: 26 September 2014 (online \& print)

Manuscript details: Ms \# 03748 | Received 14 August 2013 | Final received 19 May 2014 | Finally accepted 09 September 2014

Citation: Luczon, A.U., I.K.C. Fontanilla, P.S. Ong, Z.U. Basiao, A.M.T. Sumaya \& J.P. Quilang (2014). Genetic diversity of the Critically Endangered Philippine Eagle Pithecophaga jefferyi (Aves: Accipitridae) and notes on its conservation. Journal of Threatened Taxa 6(10): 6335-6344; http://dx.doi.org/10.11609/JoTT. 03748.6335-44

Copyright: @ Luczon et al. 2014. Creative Commons Attribution 4.0 International License. JoTT allows unrestricted use of this article in any medium, reproduction and distribution by providing adequate credit to the authors and the source of publication.

Funding: We gratefully acknowledge the following for providing funding for this study: University of the Philippines Office of the Vice-President for Academic Affairs for the Emerging Science and Technology Grant; the UP Diliman Chancellor through an Outright Research Grant from the Office of the Vice Chancellor for Research and Development (111110 PNSE)

Competing Interest: The authors declare no competing interests.

Acknowledgements: We gratefully acknowledge the Energy Development Corporation and the Philippine Eagle Foundation (PEF) and Department of Environment and Natural Resources - Bidiversity Management Bureau for providing the samples used in this study.
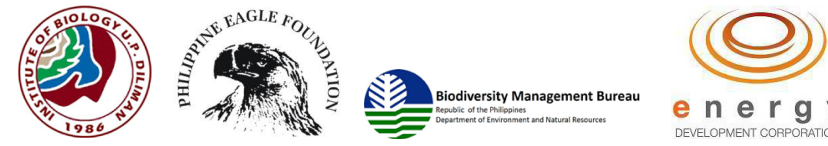

e n e r g y

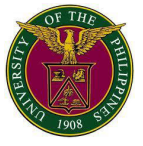




\section{INTRODUCTION}

Family Accipitridae includes eagles, kites, goshawks, hawk-eagles and Old World vultures. The Philippine Eagle Pithecophaga jefferyi is a diurnal raptor that was initially thought to be closely related to large carnivorous birds of the subfamily Harpiinae, such as the Harpy Eagle Harpia harpyja and the Crested Eagle Morphnus guianensis, based on size and morphology (Peters 1931). However, genetic analysis revealed that the Philippine Eagle is distinct from these species based on two mitochondrial regions and a nuclear intron, and more closely related to smaller species of snakeeagles of the subfamily Circaetinae (Lerner \& Mindell 2005). The accipitrids are some of the most endangered species of raptors, with dwindling numbers attributed to habitat loss and other anthropogenic activities (Lerner \& Mindell 2005). The Philippine Eagle is restricted to only four islands in the Philippines: Luzon, Samar, Leyte and Mindanao (Rabor 1971; Kennedy 1977). These eagles nest in tall trees usually in steep slopes near rivers and tributaries within mature dipterocarp forests (Kennedy 1977), and the observation that they prey on monkeys led to the common name Monkey-eating Eagle and the genus name Pithecophaga. Subsequent investigations revealed that Philippine Eagles also prey on other vertebrates, including mammals, reptiles and birds (Gamauf et al. 1998; Salvador \& Ibanez 2006). These eagles have a breeding cycle that lasts around two years, with one egg being laid at a time (Kennedy 1981). t Philippine Eagle populations are continually being threatened by hunting and loss of habitat (Kennedy 1977; BirdLife International 2013), and continuing decrease in forest areas over the years has left this species under threat of extinction. A recent study estimated about 82-233 breeding pairs left in the wild in Mindanao and around 500 pairs throughout the Philippines (Bueser et al. 2003; Salvador \& Ibanez 2006). IUCN classified these raptors as Critically Endangered because of their unique breeding characteristics and the unrelenting threats they face (Birdlife International 2013).

In most cases a decrease in the population size will lead to a decrease in genetic diversity. Low genetic diversity would normally increase the inbreeding rate, which in turn would lead to the lowering of the population's overall fitness and increase the extinction risk (Brook et al. 2002). The assessment of genetic diversity undertaken in this study will inform conservation actions for this species and address problems associated with captive breeding programs already in place.

\section{MATERIALS AND METHODS}

Twenty-two individuals were studied. Feather samples from two Luzon individuals and a muscle sample from a Samar individual were provided by the Philippine Department of Environment and Natural ResourcesBiodiversity Management Bureau (DENR-BMB). Blood samples from the 19 remaining individuals were provided by the Philippine Eagle Foundation (PEF) from their captive breeding facility in Davao City, Mindanao Island. Blood extraction was performed via venipuncture by a veterinarian during the annual medical check-up of the raptors; no animals were harmed. Samples from PEF consisted of 16 individuals originating from Mindanao forests and three individuals bred in captivity, whose parents originated from Mindanao forests as well (Table 1). Localities for each Philippine Eagle included in the study are shown in Fig. 1.

DNA from muscle samples was extracted using Wizard Genomic ${ }^{\circledR}$ DNA extraction kit (Promega, USA) while feather and blood samples were extracted using DNeasy Blood and Tissue Kit (Qiagen, USA) following manufacturers' instructions.

The complete mitochondrial CR ( 1130bp) was amplified using two sets of PCR primers designed with Primer3Plus (Untergasser et al. 2007) and with reference to the complete mitochondrial genomes of Spilornis cheela (NC015887), Accipiter gentilis (NC011818), Buteo buteo (NC003128) and Spizaetus nipalensis (AP008238): a) 28v2f 5'-TGGTCTTGTAAACCAAAGACTGAA-3' and AULH28 5'-TCCTGAAGCTAGTAACATAGGACA-3'; b) LAUL30 5'-CGGACCAGGTTAGCTATTAGTCG-3' and

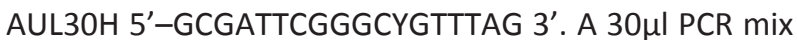
was prepared using components from Taq DNTpack (Roche, USA). The mix consisted of $22.05 \mu$ of DNAse-free water, $3 \mu \mathrm{l}$ PCR buffer (100 mM Tris- $\mathrm{HCl}, 15 \mathrm{mM} \mathrm{MgCl}$, $\left.500 \mathrm{mM} \mathrm{KCl}, \mathrm{pH} 8.3\left[20^{\circ} \mathrm{C}\right]\right), 0.6 \mu \mathrm{dNTP}(10 \mathrm{mM}), 3 \mu \mathrm{l}$ of $(1.5 \mu \mathrm{l}$ each) primer $(10 \mathrm{mM}), 0.15 \mu \mathrm{l}$ Taq polymerase $(5$ units $/ \mu \mathrm{l})$, and $1.2 \mu \mathrm{l}$ of genomic DNA template.

PCR conditions for the control region consisted of the following: an initial denaturation of $94^{\circ} \mathrm{C}$ for three minutes; 35 cycles of $94^{\circ} \mathrm{C}$ for one minute, $55^{\circ} \mathrm{C}$ for 1.5 minutes, and $72^{\circ} \mathrm{C}$ for 1.5 minutes; and a final extension of $72^{\circ} \mathrm{C}$ for five minutes. The PCR products were run on a $1 \%$ agarose gel with ethidium bromide and the bands were viewed under UV light.

Bands from the gel that matched correctly with the expected size of the fragment were excised and purified using Qiaquick ${ }^{\circledR}$ Gel Extraction Kit (Qiagen, USA), following the manufacturer's instructions. Purified PCR products were sent to 1stBASE in Selangor, Malaysia for 
Table 1. Localities where samples were obtained in this study and the control region (CR) GenBank accession numbers of each individual. PEF-individuals from the Philippine Eagle Foundation, PEL-individuals from Luzon, PEV-individual from Samar. See Figure 1 for location on map.

\begin{tabular}{|c|c|c|c|}
\hline $\begin{array}{l}\text { Specimen } \\
\text { code }\end{array}$ & Locality & $\begin{array}{l}\text { Location \# } \\
\text { on map }\end{array}$ & $\begin{array}{c}\text { CR Accession } \\
\#\end{array}$ \\
\hline PEL4 & $\begin{array}{l}\text { Barangay Asinga-Via, Baggao, } \\
\text { Cagayan }\end{array}$ & 1 & KC206401 \\
\hline PEL2 & Casala, San Mariano, Isabela & 2 & KC206400 \\
\hline PEV1 & Buluan, Calbiga, Samar & 3 & KC206402 \\
\hline PEF1 & $\begin{array}{l}\text { Montoclot, Upo Maitum, } \\
\text { Sarangani Province }\end{array}$ & 4 & KC206370 \\
\hline PEF2 & Sultan Kudarat & 5 & KC206371 \\
\hline PEF4 & Hilong-Hilong, Butuan City & 6 & KC206373 \\
\hline PEF11 & $\begin{array}{l}\text { Maasim, Saranggani Province, } \\
\text { South Cotabato }\end{array}$ & 7 & KC206378 \\
\hline PEF15 & Mati, Davao Oriental & 8 & KC206382 \\
\hline PEF17 & $\begin{array}{l}\text { Brgy. Babuyan, Carascal, } \\
\text { Surigao del Sur }\end{array}$ & 9 & KC206384 \\
\hline PEF18 & $\begin{array}{l}\text { Brgy. Tumanding, Municipality } \\
\text { of Arakan, province of } \\
\text { Cotabato }\end{array}$ & 10 & KC206385 \\
\hline PEF19 & Siocon, Zamboanga del Norte & 11 & KC206386 \\
\hline PEF21 & $\begin{array}{l}\text { Mt. Malindang, Conception, } \\
\text { Oroquieta City, Misamis } \\
\text { Occidental }\end{array}$ & 12 & KC206388 \\
\hline PEF22 & Lagonlong, Misamis Oriental & 13 & KC206389 \\
\hline PEF24 & $\begin{array}{l}\text { Mt. Kan-apo Panaosawan, } \\
\text { Bayabas, Surigao del Sur }\end{array}$ & 14 & KC206390 \\
\hline PEF29 & $\begin{array}{l}\text { So. Upper Lumbo, Brgy. } \\
\text { Cabalantian, Arakan Valley, } \\
\text { North Cotabato }\end{array}$ & 15 & KC206392 \\
\hline PEF31 & $\begin{array}{l}\text { So. Suti, Brgy. Borboanan, } \\
\text { Surigao del Sur }\end{array}$ & 16 & KC206394 \\
\hline PEF36 & Zamboanga del Sur & 17 & KC206396 \\
\hline PEF37 & $\begin{array}{l}\text { Mt. Mamjao, near Lake } \\
\text { Mainit, Santiago, Agusan del } \\
\text { Norte }\end{array}$ & 18 & KC206397 \\
\hline PEF49 & Tupi, South Cotabato & 19 & KC206399 \\
\hline $\begin{array}{l}\text { PEF14 } \\
\text { (Captive } \\
\text { bred) }\end{array}$ & $\begin{array}{l}\text { Philippine Eagle Foundation, } \\
\text { Davao }\end{array}$ & 20 & KC206416 \\
\hline $\begin{array}{l}\text { PEF3 } \\
\text { (Captive } \\
\text { bred) }\end{array}$ & $\begin{array}{l}\text { Philippine Eagle Foundation, } \\
\text { Davao }\end{array}$ & 20 & KC206372 \\
\hline $\begin{array}{l}\text { PEF7 } \\
\text { (Captive } \\
\text { bred) }\end{array}$ & $\begin{array}{l}\text { Philippine Eagle Foundation, } \\
\text { Davao }\end{array}$ & 20 & KC206374 \\
\hline
\end{tabular}

bidirectional sequencing.

Contigs were assembled and primer sequences were removed using the STADEN package Version 1.5.3 (Staden et al. 2000). Sequences were submitted to GenBank and were given accession numbers (KC206370-KC206437). Sequences were aligned with BioEdit Sequence Alignment Editor Version 7.0.5.3 (Hall 1999) using the ClustalW algorithm. Unique haplotypes were determined using the software DnaSP Version 5

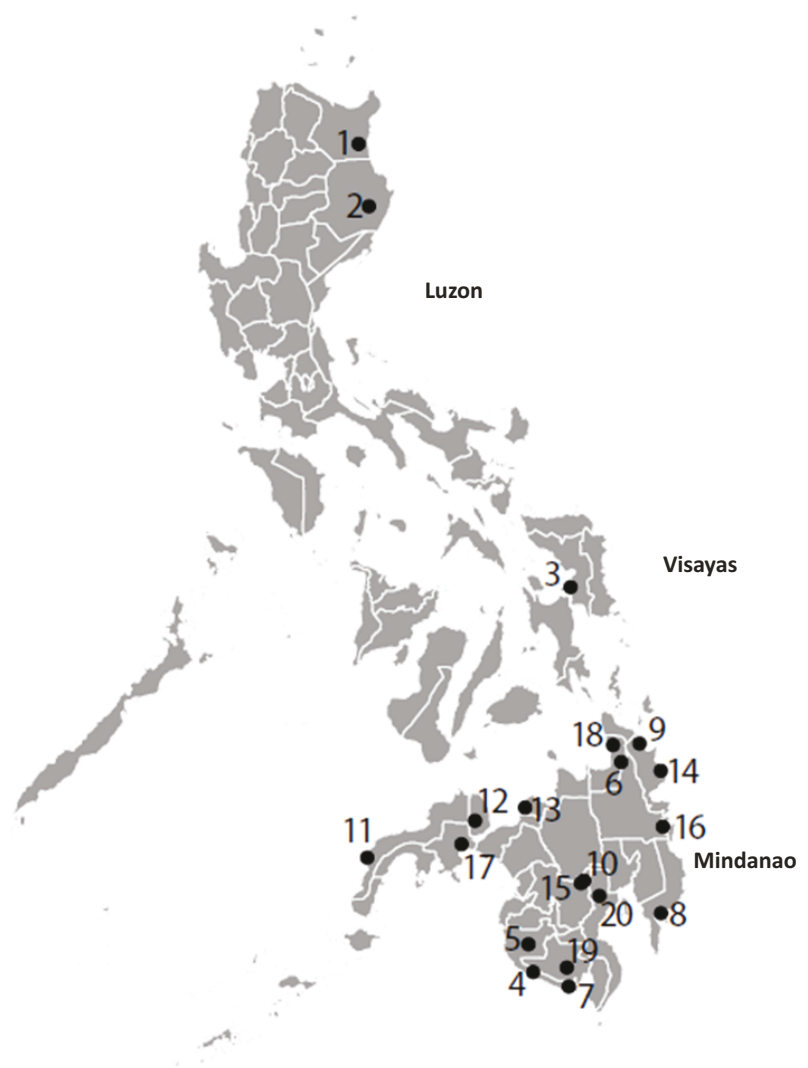

Figure 1. Map of the Philippines showing localities where Philippine Eagles were obtained. Numbers correspond to locality number in Table 1.

(Librado \& Rozas 2009).

To visualize the relationships of the haplotypes, a maximum likelihood ( $\mathrm{ML}$ ) tree and a median-joining network (Bandelt et al. 1999) were constructed. The ML tree was generated using PhyML ver. 3.0 (Guindon \& Gascuel 2003). The appropriate model for substitution frequency was determined based on Bayesian Information Criterion in jModelTest software (Posada 2008). The median-joining network was constructed using NETWORK version 4.6 (http://www.fluxusengineering.com).

Nucleotide diversity $(\pi)$ and haplotype diversity (h) were calculated in order to determine the level of genetic diversity for the Philippine Eagle population. $F_{S T}$ values were calculated in order to estimate the degree of differentiation between the different subpopulations. Analysis of Molecular Variance (AMOVA) was used to test if sequence variances are concentrated either between or within populations. Evidence for population expansion was evaluated using mismatch distributions of pairwise differences, Fu's $F_{s}$ (Fu 1997), Tajima's D (Tajima 1989) and Fu and Li's F and $D_{F}$ (Fu \& Li 1993). 
Fu's $F_{s}$ uses the number of haplotypes and average pairwise sequence divergence to test for presence of demographic expansion (Fu 1997). Tajima's D uses segregating sites average pair-wise sequence divergence to test for departures from neutrality. Fu and Li's $D_{F}$ and $F$ use an outgroup sequence in order to find recent mutations within the population which can be used as evidence for population expansion (Fu \& Li 1993). Negative values for these statistics indicate an excess of rare alleles brought about by purifying selection or population expansion (Fu \& Li 1993). Calculations for Fu and Li's $D_{F}$ and $F$ were done in DnaSP v5. The rest of the analyses were done using Arlequin suite version 3.5.1.2 (Excoffier \& Lischer 2010). The complete mitochondrial CR of the Crested Serpent-eagle (Spilornis cheela) (NC015887) was used as outgroup for the construction of the ML tree.

\section{RESULTS}

Of 22 samples analysed in this study, 14 unique control region haplotypes were observed with haplotype 1 as the most frequent. Three unique haplotypes were represented by each of the Luzon and Samar individuals, while the other 11 haplotypes were found in the Mindanao samples. The sequences varied by 36 sites, 23 indels and 13 substitutions, mostly found in domain I of the CR. The average pairwise percent difference between these haplotypes was $0.2813 \pm 0.01832 \%$. In the overall population, a high haplotype diversity ( $\mathrm{h}=$ $0.8960 \pm 0.05590)$ and low nucleotide diversity of $(\pi=$ $0.006194 \pm 0.003372$ ) were observed (Table 2).

The $\mathrm{ML}$ tree is shown in Fig. 2. The Mindanao haplotypes are split into three major branches, with each of the Luzon haplotypes ( $\mathrm{H} 12=$ =Isabela individual and $\mathrm{H} 13=$ Cagayan individual) placed in a different branch. The haplotype from the Samar sample (H14) was most basal. However, all nodes have either a low or moderate bootstrap support (less than $50 \%$ ).

The median-joining network generated is shown in

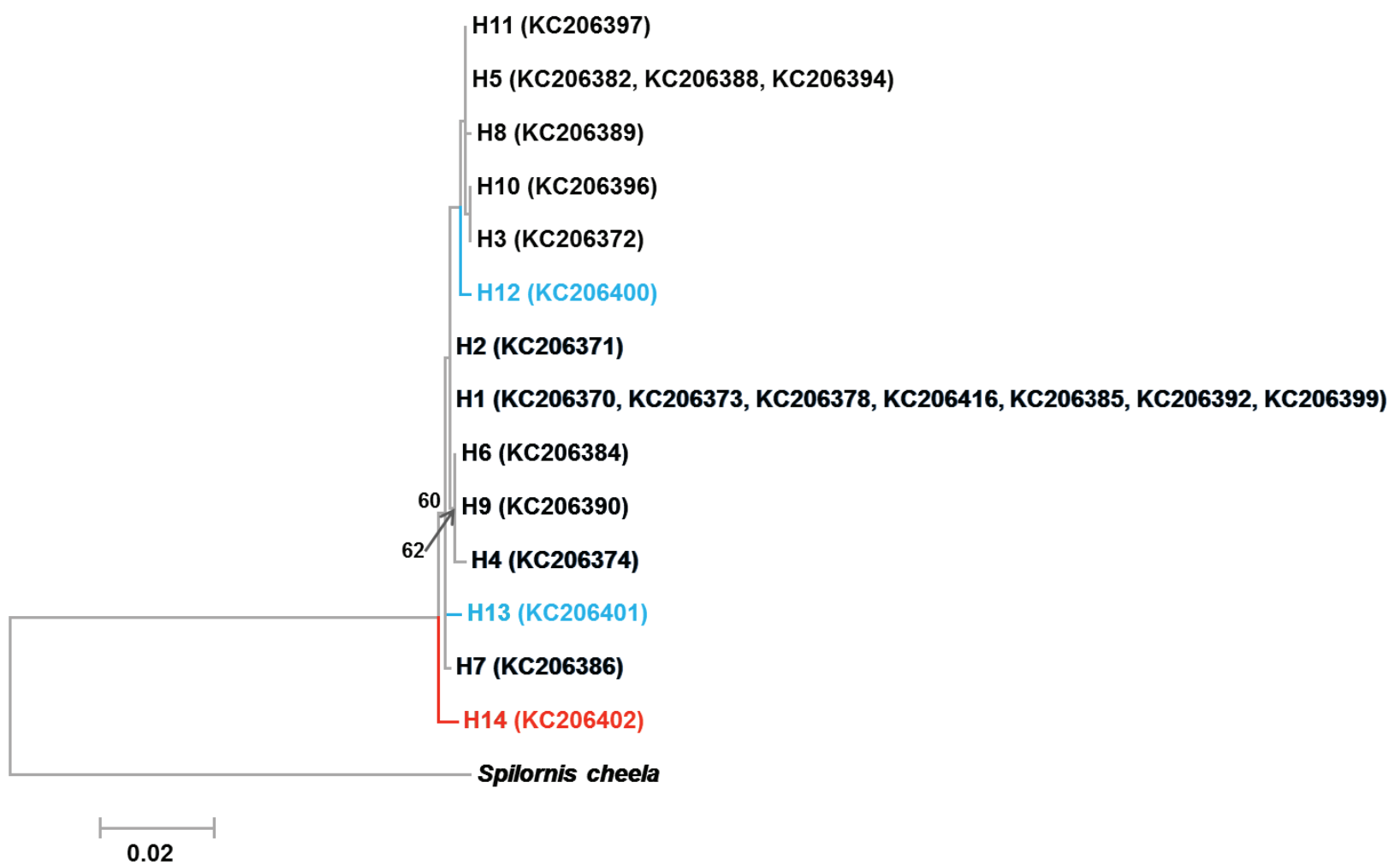

Figure 2. Maximum likelihood tree for the mitochondrial control region haplotypes of the Philippine Eagle under the HKY+G model of substitution and rooted to Spilornis cheela. $\mathrm{H}=$ haplotype, blue text=haplotypes from Luzon, red text=haplotype from Samar, black text=haplotypes from Mindanao. Only nodal supports greater than $50 \%$ are shown. Enclosed in parenthesis are the GenBank accession numbers that correspond to the control region haplotype. 
Table 2. Genetic diversity indices for each of the subpopulations of the Philippine Eagle.

\begin{tabular}{|l|c|c|c|c|c|c|}
\hline Subpopulation & No. of individuals & No. of haplotypes & $\begin{array}{c}\text { No. of unique } \\
\text { haplotypes }\end{array}$ & $\begin{array}{c}\text { No. of } \\
\text { polymorphic sites }\end{array}$ & $\begin{array}{c}\text { Haplotype } \\
\text { diversity (h) }\end{array}$ & $\begin{array}{c}\text { Nucleotide } \\
\text { diversity ( } \pi \text { ) }\end{array}$ \\
\hline Luzon & 2 & 2 & 2 & 16 & 1 \\
\hline Samar & 1 & 1 & 1 & - & -0140 \\
\hline Mindanao & 19 & 11 & 11 & 26 & - \\
\hline Overall & 22 & 14 & - & 36 & 0.8596 \\
\hline
\end{tabular}

Fig. 3. A cluster of Mindanao haplotypes ( $\mathrm{H} 1, \mathrm{H} 2, \mathrm{H} 4$, $\mathrm{H} 5, \mathrm{H} 6, \mathrm{H} 9$ and $\mathrm{H} 10$ ) form the torso of the network. The network shows that each of the Luzon ( $\mathrm{H} 12$ and $\mathrm{H} 13$ ) and Samar (H14) haplotypes stem from the torso on different branches, although the Luzon haplotypes are closer to the cluster of Mindanao haplotypes compared to the Samar haplotype. This may indicate that the Samar individual came from a different phylogeographic origin from that of the Luzon individuals.

Mismatch analysis was done for the population and is shown in Fig. 4. Results for this analysis reveal a multimodal distribution. Test of goodness of fit was assessed using the raggedness index where a nonsignificant value indicates a non-significant difference between the observed and the simulated demographic expansion model. Based on the raggedness index for

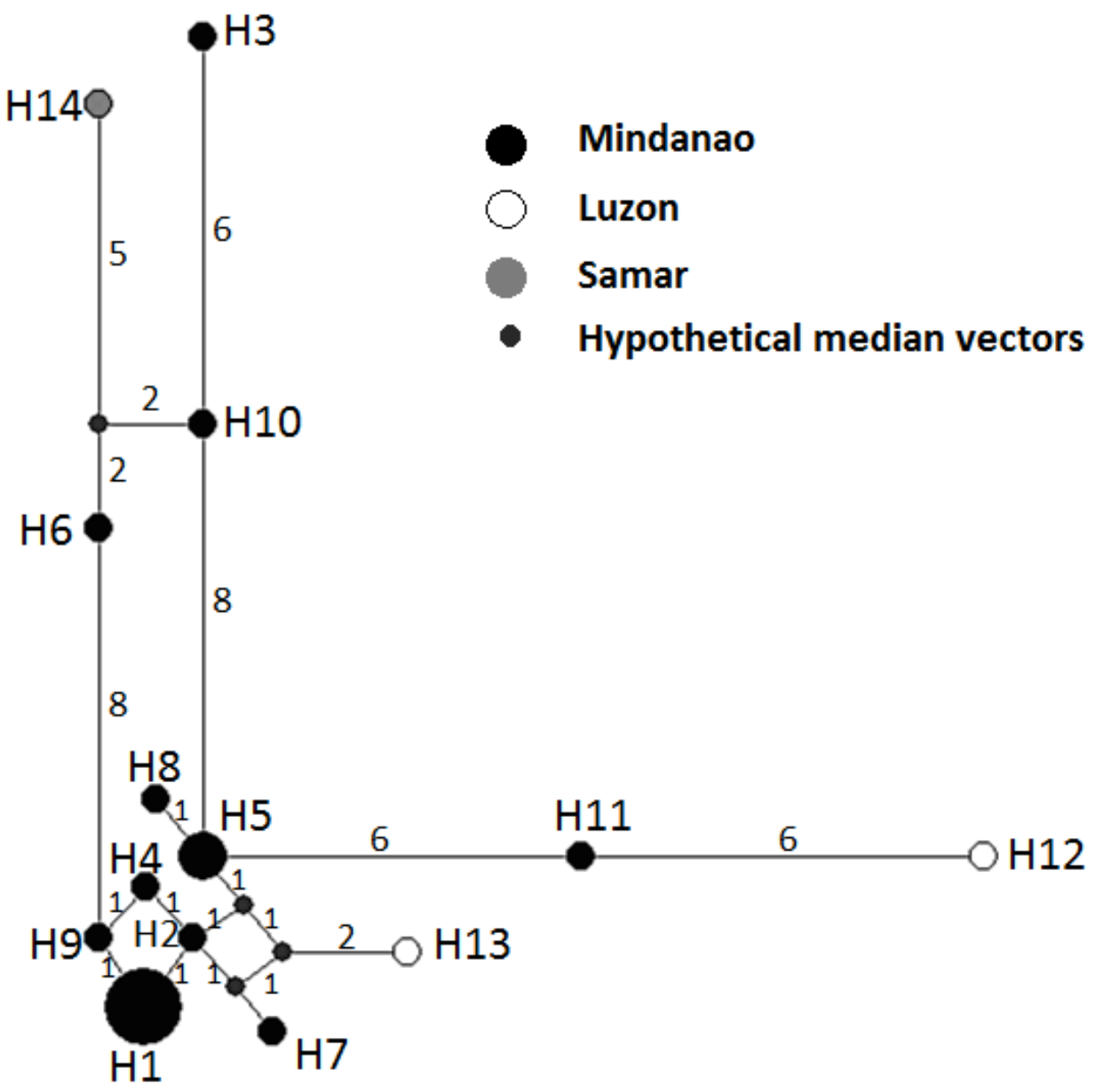

Figure 3. Median-joining network for the mitochondrial control region haplotypes of the Philippine Eagle. Circles indicate haplotypes and sizes indicate the number of individuals representing that haplotype. Black circle=Mindanao haplotypes, white circle=Luzon haplotypes, light grey circle=Samar haplotype, small dark grey circles=hypothetical median vectors. Numbers between lines denote the number of mutations between adjacent haplotypes. 


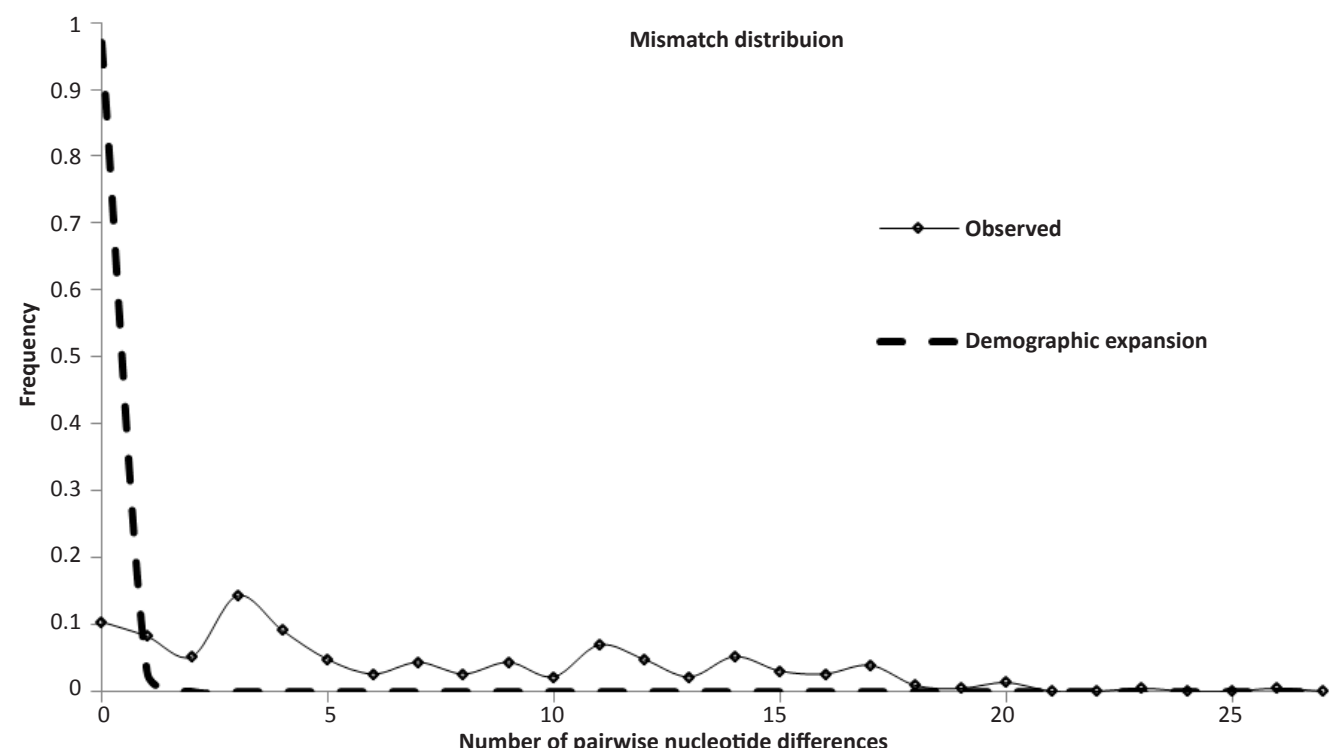

Figure 4. Mismatch distribution analysis for the mitochondrial control region of the Philippine Eagle.

Table 3. Results for Tajima's D, Fu's $F_{s}$, and Fu and Li's $F$ and $D_{F}$ of the control region.

\begin{tabular}{|c|c|c|c|c|c|c|c|}
\hline \multicolumn{2}{|c|}{ Tajima's D } & \multicolumn{2}{c|}{ Fu's $F_{s}$ test } & \multicolumn{2}{c|}{ Fu and Li's F } & \multicolumn{2}{c|}{ Fu and Li's $D_{F}$} \\
\hline$D$ & $p$ value & $F$ & $p$ value & $F$ & $p$ value & $p$ value \\
\hline-1.36291 & 0.0774 & -2.551 & 0.1477 & -1.79315 & $0.10>P>0.05$ & -1.72966 & $0.10>P>0.05$ \\
\hline
\end{tabular}

Table 4. Overall and pairwise $\mathrm{F}_{\mathrm{ST}}$ values

\begin{tabular}{|l|c|c|}
\hline Groups compared & $\mathbf{F}_{\text {ST }}$ & P-value \\
\hline Luzon and Samar & 0.1795 & 0.9990 \\
\hline Luzon and Mindanao & 0.1962 & 0.0967 \\
\hline Mindanao and Samar & 0.6065 & 0.9990 \\
\hline Overall & 0.3955 & 0.0401 \\
\hline
\end{tabular}

the test of goodness of fit of the observed data with demographic expansion model, the Philippine Eagle population has undergone a demographic expansion $(r=0.02230, P$-value $=1.0000)$.

Tajima's D test, Fu's $F_{S}$ test and Fu and Li's $F$ or $D_{F}$, however, contradict the mismatch analysis and do not support demographic expansion. Results in these statistics contained negative values; however, none of these values were significantly different from zero (Table 3), thus population expansion is not supported. Tajima's $D$ and Fu's $F_{s}$ are known to be more sensitive than mismatch distributions in detecting populations undergoing expansion (Fu 1997). Negative values of Tajima's D and Fu's F indicate an excess of single substitutions brought about by population expansion. In
Table 5. Analysis of Molecular Variance (AMOVA) within and between subpopulations of Philippine Eagle.

\begin{tabular}{|l|l|l|l|l|}
\hline $\begin{array}{l}\text { Source of } \\
\text { variation }\end{array}$ & d.f. & $\begin{array}{l}\text { Sum of } \\
\text { squares }\end{array}$ & $\begin{array}{l}\text { Variance } \\
\text { components }\end{array}$ & $\begin{array}{l}\text { Percentage of } \\
\text { variation }\end{array}$ \\
\hline $\begin{array}{l}\text { Among } \\
\text { populations } \\
\begin{array}{l}\text { Within } \\
\text { populations }\end{array}\end{array}$ & 2 & 16.694 & $1.9824 \mathrm{Va}$ & 39.55 \\
\hline Total & 21 & 74.273 & 5.0129 & 60.45 \\
\hline
\end{tabular}

addition, Fu and Li's $F$ and $D_{F}$ use an outgroup sequence to test for evidence of population expansion and are shown to be less sensitive to biases of small sample sizes (Fu \& Li 1993). $F_{S T}$ among populations were generated (Table 4). All computed $F_{S T}$ were positive. Based on Sewall Wright's hierarchical $F$ statistics, these $F_{S T}$ values indicated moderate to high genetic difference between the subpopulations. However, only the $F_{S T}$ for the overall population was significant $(P$-value $=0.0401)$. Results from AMOVA showed that most of the variations of the control region were found within populations (Table 5). 


\section{DISCUSSION AND CONCLUSION}

The sample size for this study was 22 individuals. Breeding pairs in the wild could be at most 500 (1000 individuals); however, this number may be an overestimate and it may go down to around 350 breeding pairs. The actual numbers may even decrease further if we assume that only around $40 \%$ of the habitat is used (Bueser et al. 2003). Nevertheless, the number of individuals used in this study is a good sample for a Critically Endangered species such as the Philippine Eagle (Images 1,2).

Genetic diversity of the Accipitridae was summarized in Table 3 in the study of Lerner et al. (2009). CR haplotype diversity and nucleotide diversity observed from the Philippine Eagle was comparable with values obtained from non-endangered raptors such as the Bearded Vulture Gypaetus barbatus ( $h=0.932, \pi=0.0292$, Godoy et al. 2004) and White-tailed Eagle Haliaeetus albicilla ( $h=0.746, \pi=0.00680$, Hailer et al. 2007). Genetic diversity was also comparable with other threatened raptor species such as the White-rumped Vulture Gyps bengalensis ( $\mathrm{h}=0.76$, Johnson et al. 2008), Harpy Eagle ( $h=0.906, \pi=0.0076$, Lerner et al. 2009) and in the Red Kite Milvus milvus ( $\mathrm{h}=0.610, \pi=0.0032$, Roques \& Negro 2005). These values were higher than some raptors with stable populations such as in the White-bellied

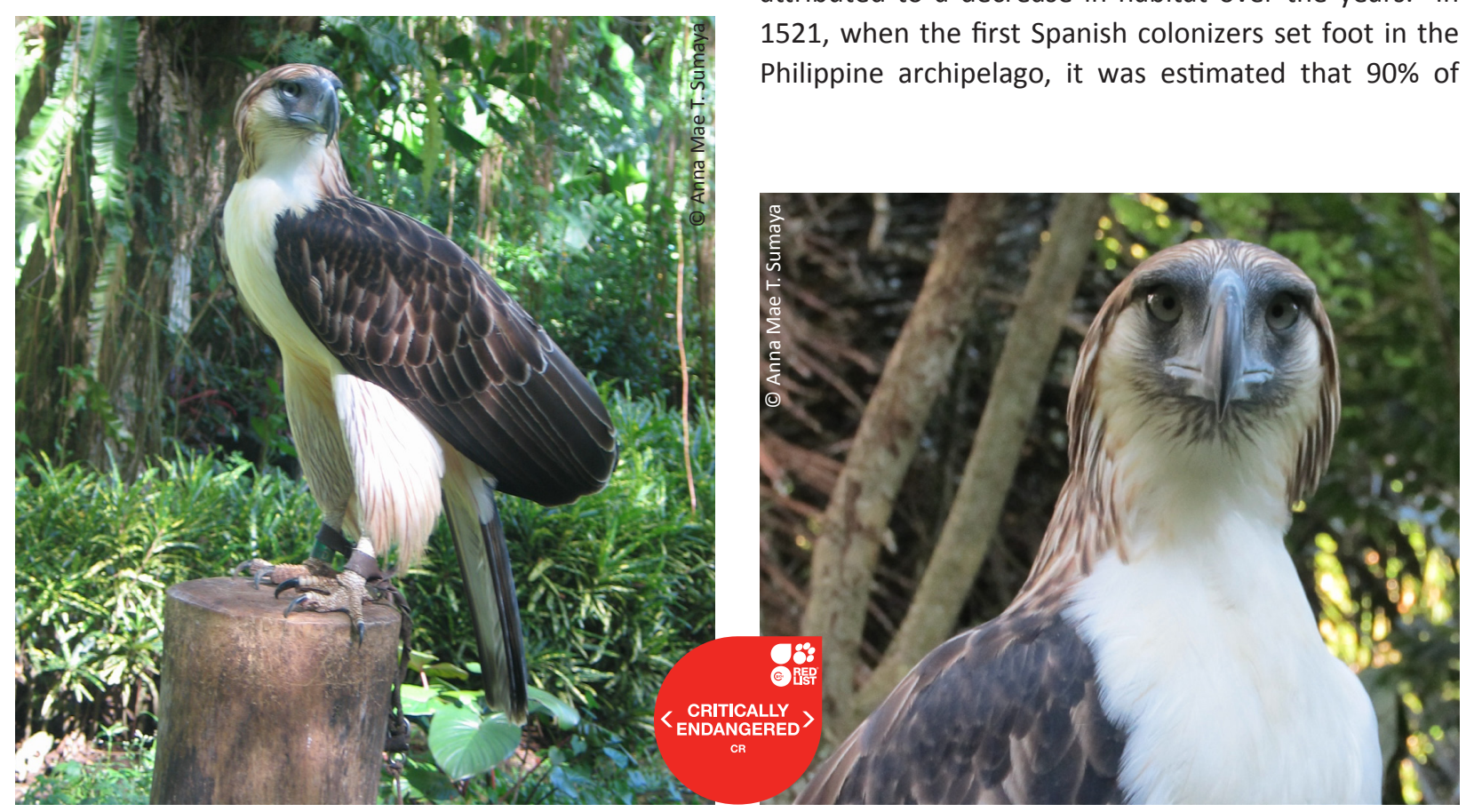

Images 1 \& 2. Philippine Eagle Pithecophaga jefferyi
Sea Eagle Haliaeetus leucogaster $(\mathrm{h}=0.350, \pi=0.000806$, Shephard et al. 2005) and in Bonelli's Eagle Aquila fasciatus ( $h=0.542, \pi=0.00240$, Cadahia et al. 2007). It should be noted that the Philippine Eagle, in contrast to these taxa mentioned, is an island species whereas the other raptors species inhabit huge distribution ranges.

High haplotype diversities and low nucleotide diversities may indicate a population bottleneck followed by demographic expansion (Grant \& Bowen 1998). This, however, should not be used to disprove a recent population bottleneck, since long-lived species have been known to retain high genetic diversities even after experiencing a recent bottleneck (Hailer et al. 2006). Fu and Li's $F$ and $D_{F}$, Tajima's D, and Fu's $F_{S}$ do not support demographic expansion. In addition, the presence of high frequencies of lower class modes (i.e., 0 and 3 nucleotide differences in the mismatch distribution) is a pattern observed in simulations of populations that experienced a recent bottleneck, although other factors can also contribute to this scenario (Rogers \& Harpending 1992; Lerner et al. 2009). Similar patterns of mismatch distribution have been observed in some subpopulations of birds that experienced a recent bottleneck (Harpy Eagles Harpia harpyja, Lerner et al. 2009; Prairie Chickens Tympanuchus cupido, Johnson et al. 2007). Similarly, the Philippine Eagle populations may have experienced a recent bottleneck.

One possible bottleneck event for the Philippine Eagle population would be the decrease in population attributed to a decrease in habitat over the years. In 1521, when the first Spanish colonizers set foot in the Philippine archipelago, it was estimated that $90 \%$ of 
the country's land area was covered by forests, which decreased to around $71 \%$ in 1900 because of the increase in human population and agricultural demands (Environmental Science for Social Change 1999). In 1969 only an estimated $34.9 \%$ of forest covered the total land area of the country. This was also the time when Rabor (1968) warned the public about the declining population of the Philippine Eagle as a result of persistent forest exploitation and hunting (Salvador \& Ibanez 2006). In 2003 , only $23.9 \%\left(72,000 \mathrm{~km}^{2}\right)$ of forest cover remained (Forest Management Bureau 2011), of which less than $10,000 \mathrm{~km}^{2}$ are considered primary forests (Lasco et al. 2001).

Although this bottleneck event is a possibility, there is a need to include additional data to prove this. It is necessary that data from other loci are evaluated to determine recent demographic changes that could have occurred. Though it is ideal to increase the sample size, this may prove difficult for the Philippine Eagle because of constraints imposed by difficulty in sampling as well as existing Philippine laws that prohibit such activities.

$F_{S T}$ indicates that the subpopulations are isolated from each other. On the other hand, AMOVA does not support this and a clear division between Luzon, Samar and Mindanao haplotypes were not observed in the MJ network and the ML tree. The MJ network seemed to indicate that the unique haplotype of the Samar sample came from a different phylogeographic origin from that of the Luzon samples, but both could have originated from Mindanao haplotypes. However, since the Philippine Eagle population of Luzon and Samar were underrepresented in this study, this conclusion may be premature, as additional samples are required to properly evaluate the scenario. Additional samples will also be needed in order to properly evaluate the divergence of the subpopulations.

Historical pattern of gene flow for the populations of the Philippine Eagle is also lacking. For now, we can say that island populations may be isolated because, despite current research efforts to monitor its population, documentation of inter-island migrations for the species was not observed. In this respect, populations could have solely dispersed during glaciation events as recent as the late Pleistocene when the Greater Mindanao was formed (Brown \& Diesmos 2001), or further back as 11 million years ago when Mindanao was connected to Luzon (Hall 2002). Additional data is needed to confirm this. Use of nuclear markers such as microsatellites and single nucleotide polymorphisms (SNPs) on nuclear loci may also provide a more accurate interpretation about historical gene flow between island populations as well as give definitive answers about the genetic bottleneck events.

As mentioned, the high mitochondrial genetic diversity of raptors, including the Philippine Eagle, could be related to its high longevity. The species has been documented to live over 40 years in captivity, although persecution and habitat loss may have shortened their lifespan in the wild. Long-lived eagles such as the Whitetailed eagle Haliaeetus albicilla (Hailer et al. 2006), White-rumped vulture $G$. bengalensis (Johnson et al. 2008) and Harpy eagle $H$. harpyja (Lerner et al. 2009), similarly, have high mitochondrial genetic diversity. Species with a long lifespan can buffer against genetic diversity loss because of a large pool of juveniles that are more resilient to disturbances in the environment than adults (Kuo \& Janzen 2004). However, as Johnson et al. (2008) pointed out, long lived species can only buffer against genetic diversity loss if pressures against their population number will last only for short periods of time. Prolonged low population numbers will eventually decrease the species' genetic diversity.

Conservation of threatened but genetically diverse species should include ways to maintain genetic diversity in the populations in the wild. One approach is to focus on protecting and ensuring the survival of wild populations in local nest sites. For example, conservation programs in Central Europe increased the survival of $H$. albicilla populations by locating and protecting nests. During winter, they also leave uncontaminated carcasses for the eagles to feed on. It is believed that this practice led to the maintenance of the species' genetic diversity (Hailer et al. 2006).

This conservation practice on ensuring the survival of the juveniles can be applied to the Mindanao Philippine Eagle population in order to maintain its degree of genetic diversity. In the conservation of Philippine Eagles in Mindanao, local government and communities play a substantive role in undertaking this conservation practice if nests have been identified within their area. Current conservation efforts for the Philippine Eagle are primarily led by the Philippine Eagle Foundation since its establishment in 1987 through captive breeding and reintroduction to the wild of juveniles and rehabilitated individuals from where they were collected (Salvador \& Ibanez 2006). One program of PEF that conforms to the aforementioned conservation practice is the "adopt-a-nest" program where participants are enlisted to monitor and report back to PEF personnel about the breeding status within the nest. As such, this program should be given emphasis by conservationists and the Philippine government. In addition, several laws, such as 
the Republic Act 9147: Wildlife Resources Conservation and Protection Act, were enacted to protect the remaining populations of the Philippine Eagle as well as to promote its conservation.

It should be clear that although this study observed a high genetic diversity for the remaining population of the Philippine Eagle (with focus on the Mindanao population), this does not exempt this species from the danger of extinction as long as the main threats to this species, such as habitat destruction and hunting, remain. Caution must also be exercised when observing patterns for high genetic diversity in populations that have undergone a recent bottleneck since this could mask high rates of genetic drift (Kuo \& Janzen 2004). The main objective of captive breeding programs is for increasing the population of an endangered species for later introduction or reintroduction. It is undisputedly an expensive way to save a species such as the Philippine Eagle, not to mention other criticisms against captive breeding such as increase in inbreeding rate and genetic adaptation to captivity as discussed by Frankham (2008). However, with proper management of breeding individuals (Frankham 2008) and addition of individuals from the wild (Johnson et al. 2008), these problems can be prevented. Nevertheless, success of captive breeding programs can only be realized if captive bred individuals can survive and reproduce in the wild upon release. That is why it is still essential to ensure, for the Philippine Eagle, that a good range of high quality habitat is maintained and prohibiting hunting is enforced. Successes in restoring population numbers have been observed in Bald Eagles Haliaeetus leucocephalus and Peregrine Falcon Falco peregrinus (www.fws.gov).

If Philippine Eagle protection and habitat quality maintenance are properly executed, it will also result in the protection of other species that fall within the protected area (Salvador \& Ibanez 2006). Recently, the Philippine government, through the DENR-BMB, has provided additional support to stem the tide of extinction of the Philippine Eagle. More support from other institutions will definitely increase the effectiveness of these conservation efforts and eventually reverse the trend of extinction the Philippine Eagle is facing.

This study demonstrates the current genetic characteristics of the Philippine Eagle population. It is not possible to fully evaluate the genetic differentiation between island populations at this time because of low number of individuals, included for the study, from the islands of Luzon and Samar. Mismatch analysis indicate a genetic bottleneck that could have coincided with the rapid loss of forests in the mid-1900s. The Philippine Eagle showed comparable genetic diversity with other members of the family Accipitridae despite experiencing population decline. However, continued low population numbers may inevitably lead to a decrease in genetic diversity. Within the PEF, additional individuals may be needed in order to maintain the genetic diversity of the Philippine Eagle population within the captive breeding area. As a means to increase or maintain the genetic diversity of population in the wild, conservation efforts should focus on increasing juvenile survival.

For future studies, it is recommended that the sample size of the Luzon and Samar population be increased so that more haplotypes may be identified and can be used to determine the direction of migration of the Philippine Eagle and to be able to estimate genetic differentiation between populations. Information from this will help determine if introduction of individuals from Mindanao to the other islands is advisable. Museum specimens may also be used to increase the number of individuals. Other sensitive markers such as microsatellites and single nucleotide polymorphisms (SNPs) may also be used in order to be able to assess the genetic diversity of the nuclear loci.

\section{REFERENCES}

Bandelt, H.J., P. Forster \& A. Rohl (1999). Median-joining networks for inferring intraspecific phylogenies. Molecular Biology and Evolution 16: 37-48.

BirdLife International (2013). Pithecophaga jefferyi. The IUCN Red List of Threatened Species. Version 2014.2. <www.iucnredlist.org>. Downloaded on 16 September 2014.

Brook, B.W., D.W. Tonkyn, J.J. O'Grady \& R. Frankham (2002). Contirbution of inbreeding to extinction risk in threatened species. Conservation Ecology 6(1): 16.

Brown, R.M. \& A. Diesmos (2001). Application of lineage-based species concepts to Oceanic Island Frog populations: the effects of differing taxonomic philosophies on the estimation of Philippine biodiversity. Silliman Journal 42: 133-162.

Bueser, G., K. Bueser, D. Afan, D. Salvador, J. Grier, R. Kennery \& H. Miranda (2003). Distribution and nesting density of the Philippine Eagle Pithecophaga jefferyi on Mindanao Island, Philippines: what do we know after 100 years? Ibis 145: 1-130.

Cadahia, L., J.J. Negro \& U. Vicente (2007). Low mitochondrial DNA diversity in the endangered Bonelli's Eagle (Hieraaetus fasciatus) from SW Europe (Iberia) and NW Africa. Journal of Ornithology 148: 99-104; http://dx.doi.org/10.1007/s10336-006-0107-z

Environmental Science for Social Change (1999). Decline of the Philippine Forests. ESSC, Inc., Quezon City, Philippines, 1+43pp.

Excoffier, L. \& H.E.L. Lischer (2010). Arlequin suite ver. 3.5: A new series of programs to perform population genetics analyses under Linux and Windows. Molecular Ecology Resources 10: 564-567; http://dx.doi.org/10.1111/j.1755-0998.2010.02847.x

Fluxus Engineering (2011). Network version 4.6.1.0.Available at http://www.fluxus-engineering.com. On-line version dated 22 October 2011.

Forest Management Bureau (2011). Philippine Forestry Statistics. 
Forest Economics Division, Quezon City, Philippines, v+291pp.

Frankham, R. (2008). Genetic adaptation to captivity in species conservation programs. Molecular Ecology 17: 325-333; http:// dx.doi.org/10.1111/j.1365-294X.2007.03399.x

Fu, Y.X. (1997) Statistical tests of neutrality of mutations against population growth, hitchhiking and background selection. Genetics 147:915-925.

Fu, Y.X. \& W.H. Li (1993). Statistical tests of neutrality of mutations. Genetics 133: 693-709.

Gamauf, A., M. Preleuthner, M. Preleuthner \& H. Winkler (1998). Philippine birds of prey: interrelations among habitat, morphology, and behavior. The Auk 115(3): 713-726.

Godoy, J.A., J.J. Negro, F. Hiraldo \& J.A. Donazar (2004) Phylogeography, genetic structure and diversity in the endangered Bearded Vulture (Gypaetus barbatus, L.) as revealed by mitochondrial DNA. Molecular Ecology 13: 371-390; http://dx.doi. org/10.1046/j.1365-294X.2003.02075.X

Grant, W.S. \& B.W. Bowen (1998). Shallow population histories in deep evolutionary lineages of marine fishes: Insights from sardines and anchovies and lessons for conservation. Journal of Heredity 89: 415-426; http://dx.doi.org/10.1093/jhered/89.5.415

Guindon, S. \& O. Gascuel (2003). A simple, fast and accurate algorithm to estimate large phylogenies by maximum likelihood. Systematic Biology 52(5): 696-704; http://dx.doi. org/10.1080/10635150390235520

Hailer, F., B. Helander, A.O. Folkestad, S.A. Ganusevich, S. Garstad, P. Hauff, C. Koren, T. Nygard, V. Volke, C. Vila \& H. Ellegren (2006) Bottlenecked but long-lived: high genetic diversity retained in White-tailed Eagles upon recovery from population decline. Biology Letters 2: 316-319; http://dx.doi.org/10.1098/rsbl.2006.0453

Hailer, F., B. Helander, A.O. Folkestad, S.A. Ganusevich, S. Garstad, P. Hauff, C. Koren, V.B. Masterov, T. Nygard, J.A. Rudnick, S. Shiraki, K. Skarphedinsson, V. Volke, F. Wille \& C. Vila (2007). Phylogeography of the White-tailed Eagle, a generalist with large dispersal capacity. Journal of Biogeography 34(7): 1193-1206; http://dx.doi.org/10.1111/j.1365-2699.2007.01697.x

Hall, R. (2002). Cenozoic geological and plate tectonic evolution of SE Asia and the SW Pacific: computer-based reconstructions, model and animations. Journal of Asian Earth Science 353-431; http:// dx.doi.org/10.1016/S1367-9120(01)00069-4

Hall, T. (1999). Bioedit: a user-friendly biological sequence alignment editor and analysis program for Windows 95/98/NT. Nucleic Acid Symposium 41: 95-98.

Johnson, J.A., P.O. Dunn \& J.L. Bouzat (2007). Effects of recent population bottlenecks on reconstructing the demographic history of prairie-chickens. Molecular Ecology 16: 2203-2222; http:// dx.doi.org/10.1111/j.1365-294X.2007.03285.x

Johnson, J.A., M. Gilbert, M.Z. Virani, M. Asim \& D.P. Mindell (2008). Temporal genetic analysis of the critically endangered Orienta White-backed Vulture in Pakistan. Biological Conservation 141(9): 2403-2409; http://dx.doi.org/10.1016/j.biocon.2008.07.001

Kennedy, R.S. (1977). Notes on the biology and population status of the monkey-eating eagle of the Philippines. Wilson Bulletin 89(1): 1-192.

Kennedy, R.S. (1981). The air's noblest flier. Filipinas Journal of Science and Culture 2: 33-48.

Kuo, C.H. \& F.J. Janzen (2004). Genetic effects of a persistent bottleneck on a natural population of ornate box turtles (Terrapene ornata). Conservation Genetics 5: 425-437; http://dx.doi. org/10.1023/B:COGE.0000041020.54140.45

Lasco, R.D., R.G. Visco \& J.M. Pulhin (2001). Secondary Forests in the Philippines: Formation and Transformation in the $20^{\text {th }}$ Century. Journal of Tropical Forest Science 13: 652-670.
Lerner, H.R.L., J.A. Johnson, A.R. Lindsay, L.F. Kiff \& D.P. Mindell (2009). It's not too late for the Harpy Eagle (Harpia harpyja): high levels fo genetic diversity and differentiation can fuel conservation programs. Public Library of Science One 4(10): e7336; http://dx.doi. org/10.1371/journal.pone.0007336

Lerner, H.R.L. \& D.P. Mindell (2005). Phylogeny of eagles, Old World Vultures, and other Accipitridae based on nuclear and mitochondrial DNA. Molecular Phylogenetics and Evolution 37: 327-346; http:// dx.doi.org/10.1016/j.ympev.2005.04.010

Librado, P. \& J. Rozas (2009). DnaSP v5: a software for comprehensive analysis of DNA polymorphism data. Bioinformatics 25: 1451-1452; http://dx.doi.org/10.1093/bioinformatics/btp187

Peters, J.L. (1931). Check-list of the birds of the world. Vol. 1. Cambridge: Harvard University Press.

Posada, D. (2008). jModelTest: phylogenetic model averaging. Molecular Biology and Evolution 25: 1253-1256; http://dx.doi. org/10.1093/molbev/msn083

Rabor, D.S. (1971). The present status of the conservation of the Monkey-eating Eagle of the Philippines. Philippine Geography Journal 15: 90-103.

Rogers, A.R. \& H. Harpending (1992). Population growth makes waves in the distribution of pairwise genetic differences. Molecular Biology and Evolution 9(3): 552-569.

Roques, S. \& J.J. Negro (2005). MtDNA genetic diversity and population history of a dwindling raptorial bird, the red kite (Milvus milvus). Biological Conservation 126: 41-50; http://dx.doi.org/10.1016/j. biocon.2005.04.020

Salvador, D.J. \& J.C. Ibanez (2006). Ecology and conservation of Philippine Eagles. Ornithological Science 5: 171-176.

Shephard, J.M., H.M. Hughes, C.P. Catterall \& P.D. Olsen (2005). Conservation status of the White-bellied Sea-Eagle Haliaeetus leucogaster in Australia determined using mtDNA control region. Conservation Genetics 6: 413-429.

Staden, R.K., K.F. Beal \& J.K. Bonfield (2000). The Staden package, 1998. Methods in Molecular Biology 132: 115-130.

Tajima, F. (1989). Statistical method for testing the neutral mutational hypothesis by DNA polymeration. Genetics 123: 585-595.

Untergasser, A., H. Nijveen, X. Rao, T. Bisseling, R. Geurts \& J.A.M. Leunissen (2007). Primer3Plus, an enhanced web interface to Primer3. Nucleic Acids Research 35: W71-W74; http://dx.doi. org/10.1093/nar/gkm306

US Fish and Wildlife Service (2013). www.fws.gov. On-line version dated 12 March 2013.

Author Contribution: ADRIAN U. LUCZON was directly involved in designing, undertaking the study and preparation of manuscript. JONAS P. QUILANG was involved in designing the study, preparation of manuscript and arrangement of funding. ANNA MAE T. SUMAYA was involved in sampling. DR. IAN KENDRICH C. Fontanilla, Dr. Perry S. ONG, and DR. Zubaida U. BAsiaO were involved in preparation of manuscript as well as arrangement of funding.

Author Details: AUL is a recent graduate of MS Biology whose interest include conservation of Philippine species using genetic tools like population genetics and phylogenetics. IKCF is interested in molecular phylogeny and DNA barcoding of species particularly in the field of Malacology. PSO is interested in biodiversity conservation using ecological tools as well as DNA barcoding. ZUB is interested in development of and improvement of cultured fish. AMTS is interested in captive breeding and conservation of the Philippine Eagle and other raptors. JPQ is interested in population genetics and DNA barcoding as tools in conservation of marine and fresh water fish. 